\title{
RESEARCH NOTE \\ Root variability among yellow lupin (Lupinus luteus L.) accessions grown at low temperatures in an undisturbed substrate
}

\author{
Claudia E. Osorio 1 , Gustavo del Canto ${ }^{1}$, Annally Rupayán ${ }^{1}$, Nicole Lichtin", \\ and Iván J. Maureira-Butler ${ }^{2}$ \\ ${ }^{1}$ Agriaquaculture Nutritional Genomic Center, CGNA, Las Heras 350, Temuco, Chile. \\ ${ }^{2}$ Universidad Austral de Chile, Facultad de Ciencias Agrarias, Instituto de Producción y Sanidad Vegetal. \\ Valdivia, Chile.
}

\begin{abstract}
C.E. Osorio, G. del Canto, A. Rupayán, N. Lichtin, and I.J. Maureira-Butler. 2019. Root variability among yellow lupin (Lupinus luteus $L$.) accessions grown at low temperatures in an undisturbed substrate. Cien. Inv. Agr. 46(3): 302-309. Root variation has become an important target for geneticists, ecologists, and breeders, given its direct influence on plant adaptation, resilience to climate change, and biomass and seed yields. However, the underground nature of roots has limited the assessment of root variability in plant species. In this study, we evaluated several root traits in a sample of distinct yellow lupin accessions grown under cold conditions and at three time points. Analyses of variance showed a highly significant accession (genotype) effect on primary root length (PRL), primary root area (PRA), and total root area (TRA), indicating that at least part of the root variation was explained by a genetic component. Significant accession*time interactions for PRL and PRA suggested that root growth rates (assessed using these traits) may change over time across genotypes; however, a more extensive study including a larger number of accessions and growing times must be conducted to confirm this finding. Differences among L. luteus accessions in PRL, PRA and TRA suggest the existence of favorable variation in plantlet root traits and the possibility of breeding stronger and better-established yellow lupin plants when grown under cold conditions.
\end{abstract}

Key words: Crop root traits, noninvasive root evaluation, yellow lupin.

\section{Introduction}

Lupins are grown under a Mediterranean climate with a wet and cold winter/hot and dry summer in south-central Chile. Although lupins are highly nutritional crops (Piornos et al., 2015), growers' interest in cultivating them has

Received Feb 02, 2018. Accepted Apr 30, 2019. Corresponding author: ivan.maureira@uach.cl fluctuated across years, mostly due to low and variable yields. In fact, the lupin cropping area varied between 10,000 and 30,000 ha during the 2000-2014 period (ODEPA, 2014). Research on narrow-leafed lupin (Lupinus angustifolius L.) has shown that water deficit negatively affects assimilation (Turner and Henson, 1989), to the point of ending vegetative and reproductive growth (French and Turner, 1991; Palta and Plaut, 1999), explaining most yield reductions 
and variability (Dracup et al., 1998; Palta and Plaut, 1999). Given that grain filling happens at the end of the rainy season, an important amount of the water used by lupins comes from the soil reservoir. Crops with well-established, deep, and high-branch-density roots would be highly desirable to achieve high yields, especially in rainfed agricultural systems (Wasson et al., 2012). This condition is usually achieved during winter cropping, given that crop roots generally grow larger in winter than in spring (ThorupKristensen et al., 2009). However, a common setback associated with winter cropping is limited plantlet survival due to frost heaving and damage (Lejeune-Hénaut et al., 2008). This phenomenon usually generates lower plant densities and thus compromises high and stable yields at the end of a cropping season (Li et al., 2016).

Although root traits are an important target for crop improvement (Den Herder et al., 2010; Gamuyao et al., 2012; Munns et al., 2012), their underground nature has limited their genetic study. Early research on lupin root morphology identified a wide range of rooting patterns across species, from dominant taproots to lateral roots overcoming the main central branch (Clements et al., 1993). Studies carried out in L. angustifolius found that, in general, narrow-leafed lupin possesses a primary taproot and first-order lateral roots, with densely or sparsely distributed second-order branches (Chen et al., 2012). However, high variation has been observed in most root traits across wild $L$. angustifolius accessions (Chen et al., 2012). Recently, root trait diversity studies identified a number of Diversity Arrays Technology (DArT) markers associated with several root traits in narrow-leafed lupin, with individual markers explaining from 6.4 to $21.8 \%$ of the phenotypic variation (Chen et al., 2016). Identifying the genetic factors responsible for differences in root structure and architecture will not only allow the genetic dissection of important root traits but also facilitate the improvement of lupin adaptation to different edaphic environments (Chen et al., 2016).
L. luteus, an Old World cultivated lupin, shows higher protein seed content (Glencross et al., 2003; Piornos et al., 2015) and twice the amount of seed cysteine and methionine than most lupin species (Glencross et al., 2004). However, its orphan condition has placed it in the backseat of crop genetics, especially when compared to other legume species (Li et al., 2014) and main crops such as wheat, corn and rice (McCouch et al., 2016; Rodgers-Melnick et al., 2016; Uauy, 2017). Microsatellite and InDel maker data have revealed a moderate to low level of genetic variation across L. luteus accessions (Osorio et al., 2018; Parra-Gonzalez, et al., 2012; Parra Gonzalez et al., 2010), suggesting a limited amount of genetic diversity in this legume crop and thus compromising the success of breeding strategies. The goal of this study was to evaluate several root traits across a diverse sample of L. luteus genotypes to assess root phenotypic diversity in plants grown at low temperatures. It is expected that uncovering favorable plantlet root variation under winter conditions will facilitate the selection of genotypes with lower susceptibility to frost heaving and damage.

\section{Materials and Methods}

\section{Plant material}

Four diverse L. luteus accessions, namely, Core 98, Core 195, Core 226, and Core 227, were selected and included in the study. Accession selection was based on previous genetic distance results (Osorio et al., 2018; Parra-Gonzalez et al., 2012) and distinct countries of origin to maximize genetic differences among genotypes. Core 98 (PI 385149 , Spain) was obtained from the Western Regional PI Station, USDA; Core 226 (accession number LLUTDZM6) was kindly provided by Dr. Abdelkader Ainouche at the Univ. Of Rennes, France; and Core 195 (accession LlCGNA-101) and Core 227 (accession IMB-L0060) are Chilean breeding lines obtained from the Agri Aquaculture Nutritional Genomic Center, Chile. The acces- 
sions were replicated four times and evaluated under a completely randomized design with a bifactorial arrangement, where accession and time were considered factors.

\section{Growth chamber experiment}

Several uniform seeds per accession were surfacesterilized following standard procedures (Clark et al., 2011; Khandual and Reddy, 2014), with minor modifications. Briefly, seeds were initially sterilized using $70 \%$ ethanol for one minute and later transferred into a $3 \%$ sodium hypochlorite solution for 10 minutes with gentle shaking. Seeds were finally washed three times with MQ sterile water. Sterilized seeds were then placed in sterile Petri dishes filled with moist filter paper. Seeds were germinated under dark conditions for 48 $\mathrm{h}$ at $20^{\circ} \mathrm{C}$. Germinating seeds were later transferred into 50-cm-tall/60-mm-wide borosilicate glass cylinders containing $800 \mathrm{~mL}$ of modified Magnavacca's growth medium (Famoso et al., 2010). One germinated seed was placed in each glass cylinder, and only seeds showing 1-cm-long radicles were selected. Magnavacca's growth medium was solidified with $0.6 \%$ Phytagel ${ }^{\circledR}$ (Sigma-Aldrich, USA). All cylinders were placed in a growth chamber, and the seedlings were allowed to grow for 28 days at $8{ }^{\circ} \mathrm{C}$ under a 16 $\mathrm{h}$ light $\left(115 \mu \mathrm{mol} \mathrm{m} \mathrm{m}^{-2} \mathrm{~s}^{-1}\right) / 8 \mathrm{~h}$ dark photoperiod and $60 \%$ humidity. The sections of the cylinders containing medium were covered with aluminum foil to reduce root light exposure.

\section{Root measurements}

Several root traits were evaluated during the experiment: primary root length (PRL), primary root (or taproot) area (PRA), secondary root area (SRA), and total root area (TRA). All traits were evaluated three times at 9, 22, and 28 days after germination. At each time, a series of four pictures were taken by a Canon EOS 6D digital camera (C Canon Latin America, Inc.) covering four tube angles $\left(0,45,90\right.$ and $\left.180^{\circ}\right)$. Later, images were analyzed using ImageJ software (Schneider et al., 2012). For area measurement-related traits (PRA and SRA), the image taken at the angle showing the highest value was selected for statistical analysis. Analyses of variance (ANOVAs) were carried out to examine variation among genotypes at different times. Variances were analyzed using the MIXED model procedure in SAS 9.3 for Windows (SAS Institute Inc., Cary, NC), and replicate was considered a random effect. Least square means (lsmeans) were estimated for each accession using the LSMEAN command implemented in SAS (SAS Institute Inc., Cary, NC).

\section{Results and Discussion}

Despite variable grain yield, lupins remain an attractive alternative for Chilean farming systems due to their value as a rotation crop for cereals and rapeseed. Lupins are important contributors to the farming nitrogen economy and provide weed and disease breaks (Palta et al., 2008). However, breeding efforts should focus on key traits to maximize seed yields and thus stabilize lupin productivity every cropping season. Root traits are an important target for crop improvement due to their obvious influence on stabilizing or boosting yields (Den Herder et al., 2010; Gamuyao et al., 2012; Munns et al., 2012). In this research, we evaluated several root traits to assess root phenotypic variation across a diverse sample of yellow lupin accessions. PRL, PRA, SRA, and TRA were measured for roots grown at low temperatures to mimic early germination and growth conditions (Fig. 1), typically occurring during winter and early spring, respectively. Analyses of variance (Table 1) revealed a significant accession effect for all traits but SRA, indicating that at least part of the root variation was explained by a genetic component. Studies conducted on L. angustifolius found that an important fraction of the phenotypic variation was explained by marker-phenotype associations, with several associations having $\mathrm{R}^{2}$ values above $10 \%$ (Chen et al., 2016). This sug- 
gests important genetic control of root traits. The presence of an interaction between accession and time for PRL and PRA indicates that root growth rates across genotypes may change over time; however, a more extensive experiment including a larger number of accessions and growing times should be conducted before making any definitive inferences.

Figure 2 shows root traits across $L$. luteus accessions and sampling times. Among the root traits, PRL, PRA and TRA showed clear differences among accessions. For example, Core 98 exhibited the lowest values for PRL, PRA, and TRA in most of the evaluations. This genotype is a wild Portuguese accession (Parra-Gonzalez et al., 2012), and its low root growth could be explained by either its adaptation to warmer growing conditions or a lack of domestication and breeding for fast germination and plantlet establishment. Core 227 was the accession with the fastest root growth rate. Core 227 is a single-seed descendant genotype derived from a Polish accession and selected under cold temperate conditions. Studies conducted on sorghum have shown that emergence and root establishment are key determinants of the development and survival of plants growing under chilling stress (Bekele et al., 2014). In addition, the physiological mechanisms responsible for survival under chilling were under the control of highly interactive epistatic quantitative trait loci hotspots (Bekele et al., 2014). The identification of favorable variation responsible for fast root growth under early cold growing conditions will be useful for generating better-established yellow lupin plants and ultimately increase the odds of obtaining high and stable yields at the end of a cropping season (Li et al., 2016). In addition, the generation of reliable and relevant root trait information will facilitate the understanding of root/soil interactions and crop yield potentials (Clark et al., 2011; Downie et al., 2015).

The main conclusions are as follows. The evaluation of yellow lupin plantlet roots grown under cold conditions uncovered a significant genotype effect for most of the assessed root traits, suggesting that at least part of the observed phenotypic variation was under genetic control. In addition, differences among L. luteus accessions in PRL, PRT and TRA suggested the existence of favorable variation that could be used in yellow lupin breeding programs to improve root traits of plants grown under winter conditions.

\section{Acknowledgments}

The authors acknowledge financial support from the National Commission for Scientific \& Technological Research (FONDECYT Project 1140944). We thank D. F. Calderini for comments on the manuscript.

Table 1. Analyses of variance and fixed effects for several root traits. PRL, primary root length; PRA, primary root area; SRA, secondary root area; TRA, total root area.

\begin{tabular}{|c|c|c|c|c|}
\hline & $\begin{array}{l}\text { ANOVA - Fixed } \\
\text { Effects }\end{array}$ & & & \\
\hline & PRL & PRA & SRA & TRA \\
\hline Effect & $\operatorname{Pr}>F$ & $\operatorname{Pr}>F$ & $\operatorname{Pr}>F$ & $\operatorname{Pr}>F$ \\
\hline Accession & $<.0001$ & $<.0001$ & 0.1617 & $<.0001$ \\
\hline Time & $<.0001$ & $<.0001$ & $<.0001$ & $<.0001$ \\
\hline Accession*Time & 0.0031 & 0.0071 & 0.1823 & 0.0978 \\
\hline
\end{tabular}




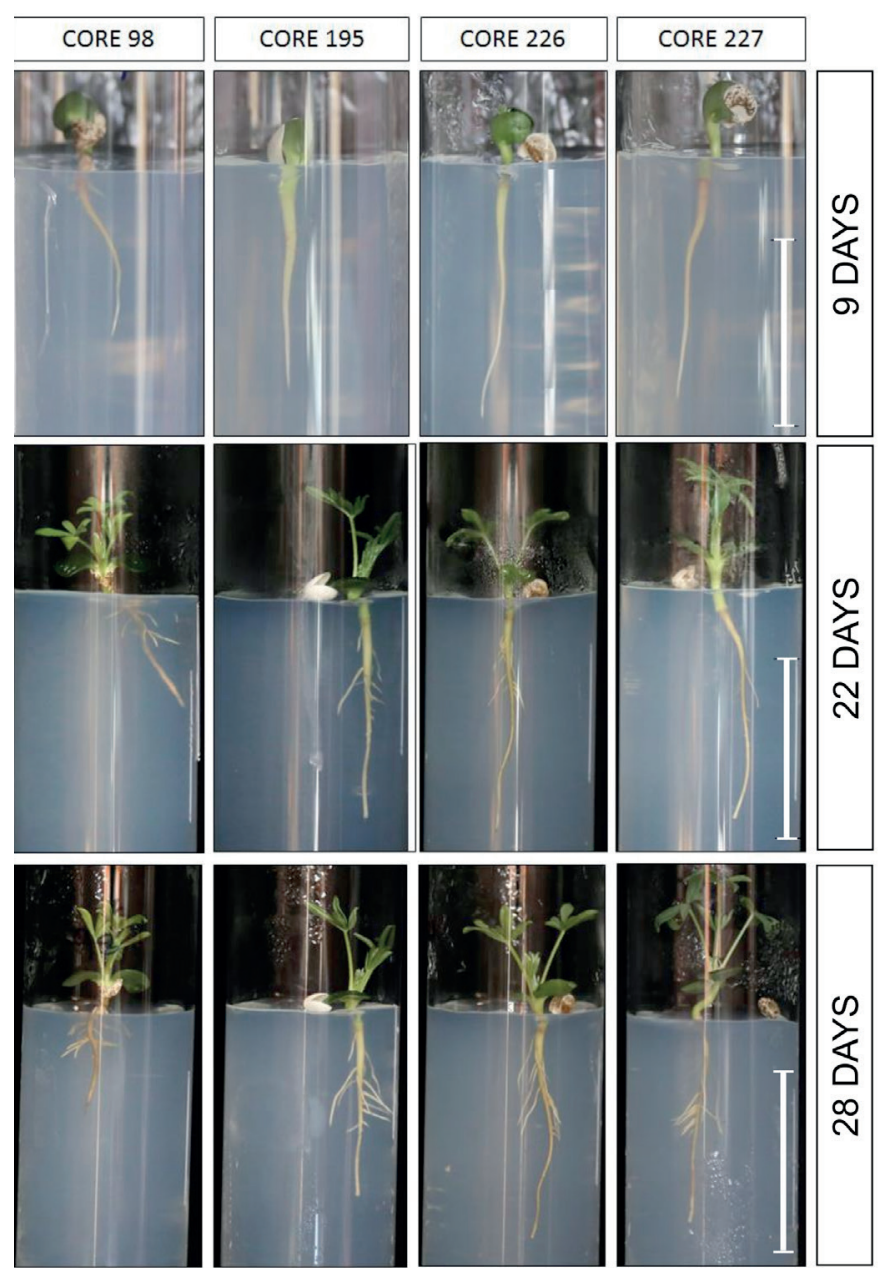

Figure 1. L. luteus plants grown in a transparent substrate at $8^{\circ} \mathrm{C}$. Root traits were measured at 9,22 , and 28 days after germination. Yellow lupin accessions: Core 98, Core 195, Core 226, and Core 227. White bar: $60 \mathrm{~mm}$.
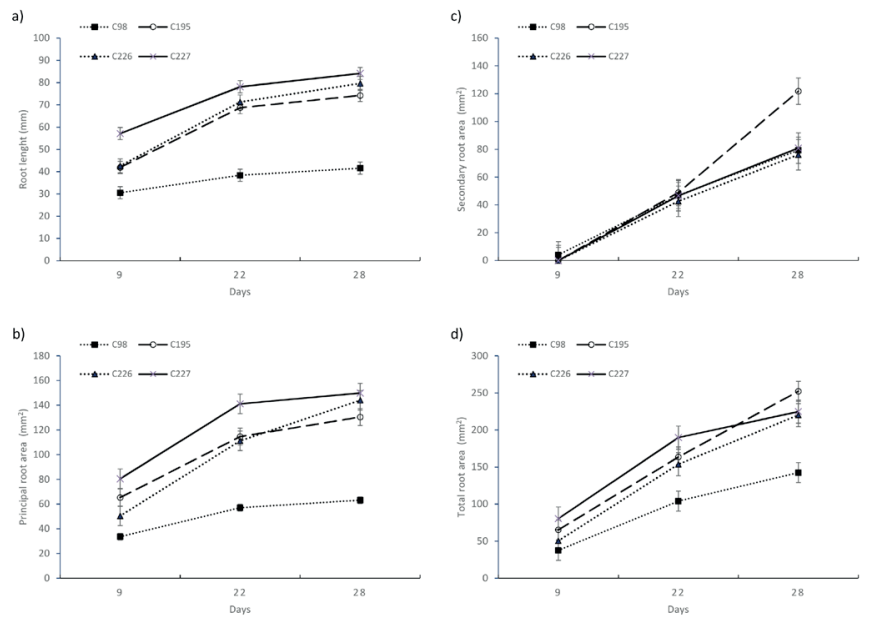

Figure 2. Root growth traits across L. luteus accessions and time. a) PRL, primary root length; b) PRA, primary root area; c) SRA, secondary root area; d) TRA, total root area. C98, C195, C226, and C227: L. luteus accessions. Vertical bars correspond to standard errors. 


\section{Resumen}

C.E. Osorio, G. del Canto, A. Rupayán, N. Lichtin, y I.J. Maureira-Butler. 2018. Variabilidad radicular en accesiones de lupino amarillo (Lupinus luteus L.) crecidos a bajas temperaturas en un sustrato no perturbado. Cien. Inv. Agr. 46(3): 302-309. La variación fenotípica de las raíces se ha convertido en un objetivo importante para genetistas, ecólogos y mejoradores, dada su influencia directa sobre la adaptación de las plantas, la resistencia al cambio climático, biomasa y el rendimiento de las semillas. Sin embargo, su naturaleza subterránea ha limitado la evaluación de la variabilidad contenida en las especies vegetales. En este estudio se evaluaron caracteres de la raíz en una muestra de accesiones diversas de lupino amarillo, cultivadas bajo condiciones de frío y durante tres puntos de su desarrollo. Análisis de varianza mostraron que la longitud de raíz primaria (LRP), el área de raíz primaria (ARP) y el área de raíz total (ART) fueron altamente significativas para el efecto accesión (genotipo), señalando que al menos parte de la variación observada se explicaría por un componente genético. Las interacciones significativas de accesión*tiempo, para LR y ARP, sugirieron que las tasas de crecimiento de raíz para los distintos genotipos pueden cambiar con el tiempo; sin embargo, más estudios, incluyendo un mayor número de accesiones y tiempos de crecimiento, deben realizarse para confirmar este hallazgo. Diferencias entre las accesiones de L. luteus para LR, ARP y ART sugieren la existencia de variación favorable para los caracteres de raíz y la posibilidad de mejorar plantas de lupino amarillo más robustas y mejor establecidas cuando se cultiven bajo condiciones frías.

Palabras clave: Caracteres radicales de cultivos, evaluaciones no disruptivas de raíces, lupino amarillo.

\section{References}

Bekele, W.A., K. Fiedler, A. Shiringani, D. Schnaubelt, S. Windpassinger, R. Uptmoor, et al. 2014. Unravelling the genetic complexity of sorghum seedling development under low-temperature conditions. Plant, Cell \& Environment 37:707723. doi:10.1111/pce.12189.

Chen, Y., F. Shan, M.N. Nelson, K.H.M. Siddique, and Z. Rengel. 2016. Root trait diversity, molecular marker diversity, and trait-marker associations in a core collection of Lupinus angustifolius. Journal of Experimental Botany 67:36833697. doi:10.1093/jxb/erw127.

Chen, Y.L., V.M. Dunbabin, A.J. Diggle, K.H.M. Siddique, and Z. Rengel. 2012. Assessing variability in root traits of wild Lupinus angustifolius germplasm: basis for modelling root system structure. Plant and Soil 354:141155. doi:10.1007/s11104011-1050-1.

Clark, R.T., R.B. MacCurdy, J.K. Jung, J.E. Shaff, S.R. McCouch, D.J. Aneshansley, et al. 2011.
Three-dimensional root phenotyping with a novel imaging and software platform. Plant physiology 156:455465.

Clements, J., P. White, and B. Buirchell. 1993. The root morphology of Lupinus angustifolius in relation to other Lupinus species. Australian Journal of Agricultural Research 44:13671375. doi: 10.1071/AR9931367.

Den Herder, G., G. Van Isterdael, T. Beeckman, and I. De Smet. 2010. The roots of a new green revolution. Trends Plant Sci 15:600607. doi:10.1016/j. tplants.2010.08.009.

Downie, H., M. Adu, S. Schmidt, W. Otten, L. Dupuy, P. White, et al. 2015. Challenges and opportunities for quantifying roots and rhizosphere interactions through imaging and image analysis. Plant, cell \& environment 38:12131232.

Dracup, M., M.A. Reader, and J.A. Palta. 1998. Variation in yield of narrow-leafed lupin caused by terminal drought. Australian Journal of Agricultural Research 49:799810. doi: 10.1071/A97151. 
Famoso, A.N., R.T. Clark, J.E. Shaff, E. Craft, S.R. McCouch, and L.V. Kochian. 2010. Development of a novel aluminum tolerance phenotyping platform used for comparisons of cereal aluminum tolerance and investigations into rice aluminum tolerance mechanisms. Plant Physiology 153:16781691.

French, R., and N. Turner. 1991. Water deficits change dry matter partitioning and seed yield in narrow-leafed lupins (Lupinus angustifolius L.). Australian Journal of Agricultural Research 42:471484. doi: 10.1071/AR9910471.

Gamuyao, R., J.H. Chin, J. Pariasca-Tanaka, P. Pesaresi, S. Catausan, C. Dalid, et al. 2012. The protein kinase Pstoll from traditional rice confers tolerance of phosphorus deficiency. Nature 488:535539. doi:10.1038/nature11346.

Glencross, B., J. Curnow, and W. Hawkins. 2003. Assessment of the nutritional variability of lupins as an aquaculture feed ingredient. Final Report for the Grains Research Committee of WA Project Fisheries Research Contract Report.

Glencross, B., D. Evans, W. Hawkins, and B. Jones. 2004. Evaluation of dietary inclusion of yellow lupin (Lupinus luteus) kernel meal on the growth, feed utilisation and tissue histology of rainbow trout (Oncorhynchus mykiss). Aquaculture 235:411422.

Khandual, S., and P.M. Reddy. 2014. Rapid, Efficient and High-Performance Protocol for Agrobacterium rhizogenes-Mediated Hairy Root Transformation of the Common Bean Phaseolus vulgaris. Advances in Bioscience and Biotechnology 5(4):7. doi:10.4236/abb.2014.54041.

Lejeune-Hénaut, I., E. Hanocq, L. Béthencourt, V. Fontaine, B. Delbreil, J. Morin, et al. 2008. The flowering locus $\mathrm{Hr}$ colocalizes with a major QTL affecting winter frost tolerance in Pisum sativum L. Theoretical and Applied Genetics 116:11051116. doi:10.1007/s00122-008-0739-x.

Li, X., R. Zeng, and H. Liao. 2016. Improving crop nutrient efficiency through root architecture modifications. Journal of Integrative Plant Biology 58:193202. doi:10.1111/jipb.12434.

Li, Y.H., G. Zhou, J. Ma, W. Jiang, L.G. Jin, and Z. Zhang. 2014. De novo assembly of soybean wild relatives for pan-genome analysis of diversity and agronomic traits. Nat Biotechnol. 32 . doi:10.1038/nbt.2979.

McCouch, S.R., M.H. Wright, C.-W. Tung, L.G. Maron, K.L. McNally, M. Fitzgerald, et al. 2016. Open access resources for genome-wide association mapping in rice. Nature Communications 7:10532. doi:10.1038/ncomms10532.

Munns, R., R.A. James, B. Xu, A. Athman, S.J. Conn, C. Jordans, et al. 2012. Wheat grain yield on saline soils is improved by an ancestral $\mathrm{Na}(+)$ transporter gene. Nat Biotechnol 30:360364. doi:10.1038/nbt.2120.

ODEPA. 2014. El mercado del lupino en la temporada 2014/15. In: Oficina de Estudios y Politicas Agrarias, editor ODEPA, Chile. p. 7.

Osorio, C.E., J.A. Udall, H. Salvo-Garrido, and I.J. Maureira-Butler. 2018. Development and characterization of InDel markers for Lupinus luteus L. (Fabaceae) and cross-species amplification in other Lupin species. Electronic Journal of Biotechnology. doi:https://doi.org/10.1016/j. ejbt.2017.11.002.

Palta, J., J. Berger, and C. Ludwig. 2008. The Growth and Yield of Narrow Leafed Lupin: Myths and Realities. Lupins for Health and Wealth. International Lupin Association. p. 2025.

Palta, J.A., and Z. Plaut. 1999. Yield and components of seed yield of indeterminate narrow-leafed lupin (Lupinus angustifolius L.) subjected to transient water deficit. Australian Journal of Agricultural Research 50:12251232. doi:https://doi. org/10.1071/AR97162.

Parra-Gonzalez, L.B., G.A. Aravena-Abarzua, C.S. Navarro-Navarro, J. Udall, J. Maughan, L.M. Peterson, et al. 2012. Yellow lupin (Lupinus luteus L.) transcriptome sequencing: molecular marker development and comparative studies. BMC Genomics 13:425. doi:10.1186/1471-2164-13-425.

Parra Gonzalez, L.B., S.C. Straub, J.J. Doyle, P.E. Ortega, H.E. Garrido, and I.J. Butler. 2010. Development of microsatellite markers in Lupinus luteus (Fabaceae) and cross-species amplification in other lupine species. American journal of botany 97:e72-74. doi:10.3732/ajb.1000170.

Piornos, J.A., C. Burgos-Díaz, T. Ogura, E. Mo- 
rales, M. Rubilar, I. Maureira-Butler, et al. 2015. Functional and physicochemical properties of a protein isolate from AluProt-CGNA: A novel protein-rich lupin variety (Lupinus luteus). Food Research International 76:719724. doi: 10.1016/j.foodres.2015.07.013.

Rodgers-Melnick, E., D.L. Vera, H.W. Bass, and E.S. Buckler. 2016. Open chromatin reveals the functional maize genome. Proceedings of the National Academy of Sciences 113:E3177E3184. doi:10.1073/pnas.1525244113.

Schneider, C., W. Rasband, and K. Eliceiri. 2012. NIH Image to ImageJ: 25 years of image analysis. Nature Methods 9:671675. doi:10.1038/ nmeth.2089.

Thorup-Kristensen, K., M. Salmerón Cortasa, and R. Loges. 2009. Winter wheat roots grow twice as deep as spring wheat roots, is this important for
$\mathrm{N}$ uptake and $\mathrm{N}$ leaching losses? Plant and Soil 322:101114. doi:10.1007/s11104-009-9898-Z.

Turner, N.C., and I.E. Henson. 1989. Comparative water relations and gas-exchange of wheat and lupins in the field. In: K. H. Kreeb, H. Richter and T. M. Hinckley, editors, Structural and functional responses to environmental stresses: water shortage. SPB Academic Publishing, The Hague. p. 293-304.

Uauy, C. 2017. Wheat genomics comes of age. Current opinion in plant biology 36: 142-148. doi: 10.1016/j.pbi.2017.01.007.

Wasson, A.P., R.A. Richards, R. Chatrath, S.C. Misra, S.V. Prasad, G.J. Rebetzke, et al. 2012. Traits and selection strategies to improve root systems and water uptake in water-limited wheat crops. J Exp Bot 63:34853498. doi:10.1093/jxb/ers111. 